\title{
PENDAPATAN DAN RISIKO USAHA TAMBAK UDANG WINDU DAN UDANG VANAME DI KECAMATAN PASIR SAKTI KABUPATEN LAMPUNG TIMUR
}

\author{
(Income and Business Risk of Tiger and Vaname Shrimp in Pasir Sakti Subdistrict \\ East Lampung District)
}

Yuni Astika Rahayu, Fembriarti Erry Prasmatiwi, Ani Suryani

Jurusan Agribisnis, Fakultas Pertanian, Universitas Lampung, Jl. Prof. Dr. Soemantri Brodjonegoro No.1 Bandar Lampung 35145, e-mail: fembriarti.erry@fp.unila.ac.id

\begin{abstract}
The purposes of this study are to analyze income and risk of shrimp cultivation, factors affecting the income, and factors affecting land conversion from cultivating tiger shrimp to vaname shrimp. The study was conducted in Purworejo Village, Pasir Sakti Subdistrict, East Lampung District, in March - April 2017 using a survey method. Respondents were 60 farmers consisting of 30 vaname shrimp farmers and 30 tiger shrimp farmers taken randomly. Data processing uses income analysis, multiple linear regression analysis, coefficient of variation analysis, and logit analysis. The results showed that the income of vaname shrimp farming was Rp53,586,604.00/ha and of tiger shrimp was Rp6,818,543.00/ha. Tiger shrimp farming has a higher risk than vaname shrimp. The level of education, farm income, and shrimp prices are negatively affect the decision-making opportunities of farmers to switch from tiger shrimp farming to vaname shrimp.
\end{abstract}

Keywords: income, risk, tiger shrimp, vaname shrimp

\section{PENDAHULUAN}

Indonesia adalah negara kepulauan yang memiliki daratan sangat luas yang mayoritas dimanfaatkan dalam bidang pertanian. Sektor pertanian mempunyai peranan strategis dalam struktur pembangunan perekonomian nasional. Hal ini ditunjukkan oleh besarnya kontribusi sektor pertanian terhadap Produk Domestik Bruto (PDB) nasional pada tahun 2014 yaitu 13,38\%. Salah satu subsektor yang memiliki kontribusi cukup besar adalah subsektor perikanan yaitu sebesar 2,24\% (BPS 2014).

Subsektor perikanan dibedakan dalam perikanan tangkap dan perikanan budidaya. Perkembangan budidaya perikanan tambak relatif cepat dibandingkan dengan perikanan lain. Hal ini ditentukan oleh daya serap pasar yang tinggi, marjin usaha besar, dikuasainya teknologi pembenihan dan berkembangnya industri sarana produksi lain (Ibrahim 2012). Komoditas perikanan budidaya tambak unggulan Provinsi Lampung adalah komoditas udang. Udang windu (Penaeus monodon) merupakan spesies udang laut yang memiliki prospek cerah karena merupakan primadona ekspor non migas dari subsektor perikanan (Kordi 2011). Udang vaname (Litopenaeus vannamei) memiliki beberapa keunggulan, yaitu produktivitasnya tinggi dengan tingkat kelangsungan hidupnya 90 persen, mudah dibudidayakan, waktu pemeliharaan lebih pendek, tahan penyakit, dan lainnya. Menurut Kristina (2014), faktor produksi yang digunakan pada budidaya udang vaname adalah penggunaan benur (benih udang), pakan udang, bahan bakar mesin dan lamanya periode pemeliharan udang vaname.

Pada saat ini potensi budidaya udang windu dan udang vaname di Lampung Timur sangat besar, seperti di Kecamatan Labuhan Maringgai dan Pasir Sakti. Kecamatan Pasir Sakti setara sentra produksi udang skala ekstensif (tradisional) dan semi ekstensif telah mengalami peralihan komoditas tebar benur udang windu ke udang vaname. Hal tersebut didukung adanya program pengabdian masyarakat berupa penerapan teknologi adaptif pada kegiatan pembenihan dan produksi pakan di Lampung Timur.

Tahun 2014 dilakukan program tambak percontohan dari Lembaga Pengabdian Masyarakat (LPM) Universitas Lampung. Hasil dari program tersebut, produksi udang vaname lebih besar daripada udang windu dengan padat tebar yang sama. Hal tersebut dikarenakan risiko pada usaha tambak udang windu lebih besar daripada udang vaname. Biaya operasional dan peralatan yang tinggi menyebabkan petambak dengan pendapatan rendah enggan melakukan usaha tambak udang vaname. 
Menurut Kementerian Kelautan dan Perikanan RI (2016), harga udang mengalami fluktuasi pada tahun 2016. Pada tahun 2017, harga jual udang windu di Kecamatan Pasir Sakti mencapai Rp75.000,00 per kg. Harga tertinggi udang windu adalah sebesar Rp135.000,00 per kg, sedangkan harga terendahnya adalah Rp53.300,00 per $\mathrm{kg}$. Harga tertinggi udang vaname mencapai Rp100.000,00 per kg, sedangkan harga terendah mencapai Rp55.000,00 per kg. Pendapatan usaha tambak udang vaname dapat mencapai Rp315.000.000,00 per ha dengan produksi 4 ton/ha. Estimasi harga jual udang vaname sekitar Rp78.000,00 per $\mathrm{kg}$ dengan biaya produksi Rp40.000,00 per kg. Estimasi biaya terbesar adalah budidaya udang yaitu hingga $60-70$ persen. Berdasarkan hal tersebut perlu diolah analisis pendapatan usaha tambak udang windu dan udang vaname, risiko usaha tambak udang, dan faktor yang mempengaruhi keputusan petambak melakukan peralihan usaha tambak udang.

\section{METODE PENELITIAN}

Metode yang digunakan pada penelitian ini adalah metode survei. Penelitian ini dilakukan di Desa Purworejo, Kecamatan Pasir Sakti, Kabupaten Lampung Timur. Lokasi penelitian ini ditentukan secara purposive dengan pertimbangan desa tersebut memiliki produksi udang windu dan udang vaname yang tertinggi di Kecamatan Pasir Sakti. Responden yang digunakan pada penelitian ini adalah petambak udang di Kecamatan Pasir Sakti. Jumlah petambak di Desa Purworejo, Kecamatan Pasir Sakti terdiri dari 40 petambak udang windu dan 100 petambak udang vaname.

Menurut Gay dan Diehl (1992), penelitian kausal perbandingan sampel yang digunakan adalah 30 subjek per kelompok. Frankel dan Wallen (1993) juga menyarankan bahwa besar sampel minimum untuk penelitian kausal perbandingan adalah sebanyak 30 per kelompok. Oleh karena itu, jumlah sampel petambak udang windu berjumlah 30 orang, dan petambak udang vaname berjumlah 30 orang. Metode pengambilan sampel menggunakan metode Simple Random Sampling (Sugiyono 2003). Pengambilan sampel juga dilakukan dengan menyeimbangkan jumlah sampel petambak udang windu dan udang vaname.

Jenis data yang digunakan dalam penelitian ini adalah data primer dan data sekunder dengan metode analisis kualitatif dan analisis kuantitatif.

\section{Analisis Pendapatan pada Usaha Tambak Udang Windu dan Udang Vaname}

Analisis pendapatan usaha tambak udang windu dan udang vaname dihitung dari selisih pendapatan total dengan biaya total dari usahatani tersebut (Soekartawi, 2006), secara matematis ditulis sebagai berikut :

$\pi=$ TR-TC

$\pi=(\mathrm{Q} \cdot \mathrm{PQ})-(\mathrm{FC}+\mathrm{VC})$

Keterangan:

$\pi \quad=$ Pendapatan usaha tambak udang (Rp)

$\mathrm{TR}=$ Total penerimaan udang $(\mathrm{Rp})$

$\mathrm{TC}=$ Total biaya usaha tambak udang $(\mathrm{Rp})$

$\mathrm{Q} \quad=$ Produksi udang $(\mathrm{kg})$

$\mathrm{PQ}=$ Harga udang (Rp)

$\mathrm{FC}=$ Biaya tetap usaha budidaya udang (Rp)

$\mathrm{VC}=$ Biaya variabel usaha tambak udang $(\mathrm{Rp})$

Untuk mengetahui usahatani tambak udang menguntungkan atau tidak, dilakukan analisis penerimaan dan biaya $(\mathrm{R} / \mathrm{C})$ sebagai berikut :

$\mathrm{R} / \mathrm{C}=\frac{\mathrm{TR}}{\mathrm{TC}}$.

Jika $\mathrm{R} / \mathrm{C}>1$, maka usaha mengalami keuntungan Jika $\mathrm{R} / \mathrm{C}=1$, maka usahatani impas.

Jika $\mathrm{R} / \mathrm{C}<1$, maka usaha mengalami kerugian.

Perbandingan pendapatan antara usaha tambak udang windu dan udang vaname dilihat dari uji beda Independen Sample Test.

\section{Analisis Risiko Usahatani Tambak Udang Windu dan Udang Vaname}

Risiko secara statistik diukur dengan ukuran ragam (variance) atau simpangan baku (standard deviation). Rumus ukuran ragam adalah :

$\mathrm{V}^{2}=\frac{\sum_{\mathrm{i}=1}^{\mathrm{n}}(\mathrm{Ei}-\mathrm{E})^{2}}{(\mathrm{n}-1)}$

Simpangan baku merupakan akar dari ragam, secara matematis dirumuskan sebagai berikut :

$\mathrm{V}=\sqrt{\frac{\sum_{\mathrm{i}=1}^{\mathrm{n}}(\mathrm{Ei}-\mathrm{E})^{2}}{(\mathrm{n}-1)}} .$.

Penentuan batas bawah untuk mengetahui jumlah hasil terbawah yang diharapkan, dirumuskan sebagai berikut:

$\mathrm{L}=\mathrm{E}-2 \mathrm{~V}$ 
Jika :

a. $\mathrm{L}>0$, maka petambak tidak mengalami rugi

b. $\mathrm{L}<0$, maka petambak mengalami kerugian

Menurut Kadarsan HW (1992), apabila nilai CV $>0,5$ maka usahatani yang dilakukan memiliki risiko yang tinggi. Untuk mengetahui perbedaan risiko usaha budidaya tambak udang windu dan udang vaname, dilakukan uji beda Independent Sample Test:

\section{Analisis Faktor-faktor yang Mempengaruhi Petambak Beralih dari Usaha Tambak Udang Windu ke Usaha Tambak Udang Vaname}

Untuk mengidentifikasi faktor-faktor yang mempengaruhi keputusan petambak udang windu beralih ke budidaya udang vaname menggunakan analisis regresi logistik (logit). Menurut Kuncoro (2004), model analisis logit adalah suatu cara untuk mengkuantitatifkan hubungan antara probabilitas dua pilihan dengan beberapa karakteristik yang dipilih.

Menurut Young (2005) dalam Pasaribu (2016), fungsi logit dapat dinyatakan dalam persamaan berikut :

$$
\begin{aligned}
& \mathrm{Zi}=\ln \frac{\mathrm{Pi}}{1-\mathrm{Pi}} \rightarrow \mathrm{Zi}=\alpha+\beta 1 \mathrm{X} 1+\beta 2 \mathrm{X} 2+\beta 3 \mathrm{X} 3+\beta 4 \mathrm{X} 4 \\
& +\beta 5 \times 5+\beta 6 \times 6+\mu \\
& \text { Keterangan : } \\
& \mathrm{Pi}=\text { Peluang petambak memilih budidaya } \\
& 1=\text { Petambak beralih ke budidaya udang } \\
& \alpha=\text { Intersep } \\
& \beta 1 . . \beta \mathrm{i}=\text { Koefisien regresi } \\
& \mathrm{X} 1=\text { Umur petambak (tahun) } \\
& \mathrm{X} 2=\text { Luas tambak (ha) } \\
& \mathrm{X} 3=\text { Pengalaman usahatani (tahun) } \\
& \mathrm{X} 4=\text { Pendidikan petambak (tahun) } \\
& \mathrm{X} 5=\text { Tingkat pendapatan }(\mathrm{Rp}) \\
& \mathrm{X} 6=\text { Harga Komoditas Udang }(\mathrm{Rp}) \\
& \mu \quad=\text { Galat atau penggangu }
\end{aligned}
$$

\section{HASIL DAN PEMBAHASAN}

\section{Keadaan Umum Responden Petambak Udang}

Umur petambak udang windu dan udang vaname berkisar antara 38-50 tahun. Sebagian besar petambak udang menempuh pendidikan rata-rata Sekolah Menengah Pertama (SMP) atau sederajat
(53 persen). Petambak udang windu dengan pengalaman usaha 16-24 tahun memiliki persentase 56 persen, sedangkan persentase udang vaname sebesar 43 persen. Jumlah tanggungan keluarga petambak udang windu dan udang vaname berkisar antara 3-4 orang.

Umur usaha tambak udang windu rata-rata adalah 12-18 tahun (60 persen), sedangkan umur usaha tambak udang vaname berkisar 1-3 tahun (96 persen). Beberapa petambak memiliki pekerjaan sampingan seperti kuli bangunan, pedagang, petani sawah, nelayan, tukang ojek, penyadap kelapa, satpam, dan peternak. Petambak udang windu sebagian besar memiliki ukuran luas kolam 1-2 ha dengan persentase 53 persen, sedangkan udang vaname memiliki luasan $<1$ ha (56 persen).

\section{Pola Budidaya Udang Windu dan Udang Vaname}

Usaha budidaya udang windu dan udang vaname merupakan suatu kegiatan yang dilakukan oleh mayoritas petambak di Kecamatan Pasir Sakti. Usaha budidaya tambak udang windu berkisar antara 90 hingga 120 hari, sedangkan pada udang vaname berkisar 75 hingga 100 hari. Kegiatan usaha tambak udang merupakan salah satu kegiatan budidaya dengan memanfaatkan kolam air payau. Pada penelitian Putri A, Widjaya S, dan Kasymir E (2018) pemeliharaan tambak pada kegiatan budidaya udang terdiri dari pemupukan susulan, pemberian pakan, vitamin, serta memonitoring pertumbuhan udang. Penebaran benur udang vaname memiliki standar 60 ekor sampai 100 ekor per $\mathrm{m}^{2}$, namun petambak melakukan tebaran sesuai modal yang dimiliki.

Hama dan penyakit merupakan kendala yang merugikan usaha budidaya udang vaname di Kecamatan Pasir Sakti. Hama yang sering menyerang adalah burung, ular, biawak, dan ikanikan liar. Aktivitas hama tersebut dapat diatasi dengan perangkap buatan untuk menangkap hama. Penyakit pada udang vaname bisa disebabkan oleh parasit, bakteri, jamur maupun virus. Faktor pemicu munculnya virus yaitu faktor nutrisi, lingkungan dan genetika. Beberapa virus yang sering menyerang adalah White Spot Syndrome Virus (WSSV), kotoran putih, dan Mio.

\section{Penggunaan Sarana Produksi dan Biaya Usaha Tambak Udang}

Sarana produksi yang digunakan pada usaha tambak udang windu dan udang vaname adalah 
benur, pakan, pupuk, pestisida, vitamin, tenaga kerja, dan peralatan. Penggunaan benur udang vaname lebih banyak daripada udang windu (139.869 ekor > 23.181 ekor) dalam 1 hektar. Harga benur udang rata-rata Rp40,00 hingga Rp48,00 per ekor. Pakan yang yang digunakan dalam budidaya udang adalah pelet dan keong. Harga pakan pelet berkisar antara Rp6.935,00 hingga Rp13.427,00 per kilogram, sedangkan pakan keong berkisar antara Rp8.000,00 hingga Rp12.000,00 per ember. Penggunaan tenaga kerja diukur setara dengan hari orang kerja (HOK) berdasarkan upah dan jam kerja tenaga kerja, yaitu Rp60.000,00 per hari.

\section{Produksi dan Penerimaan}

Usaha tambak udang windu dan udang vaname memiliki masa panen yang berbeda beda, karena adanya risiko yang dihadapi petambak. Tingkat persentase kematian udang terserang penyakit seperti WSSV mencapai 100\%. Cuaca ekstrim dan kualitas air juga dapat mempengaruhi tingkat produktivitas dari budidaya tambak udang. Kendala tersebut dapat menyebabkan produksi udang menurun.

Ukuran (size) udang windu dan udang vaname mempengaruhi harga jual udang. Semakin besar ukuran udang maka akan semakin mahal harga jual udang tersebut. Rata-rata harga jual udang vaname dan udang windu adalah Rp82.466,67 dan Rp89.700,00 per kg. Berikut informasi mengenai produksi dan penerimaan udang disajikan pada Tabel 1.

Produksi rata-rata per 1 hektar pada usaha tambak udang windu adalah $161 \mathrm{~kg}$ per hektar, sedangkan produksi udang vaname adalah $1.384 \mathrm{~kg}$ per hektar. Perbedaan produksi yang diperoleh sangat tinggi karena padat tebar yang dilakukan petambak sangat bervariasi.

Tabel 1. Produksi dan penerimaan per hektar udang windu dan udang vaname di Kecamatan Pasir Sakti

\begin{tabular}{lrr}
\hline Keterangan & Udang Vaname & Udang Windu \\
\hline Harga jual udang & $82.466,67$ & $89.700,00$ \\
Per usahatani & 1,02 ha & 1,10 ha \\
Produksi & $1.412,00$ & 178,17 \\
Penerimaan & $116.442 .938,00$ & $15.981 .849,00$ \\
Per 1 hektar & 1,00 ha & 1,00 ha \\
Produksi & $1.384,31$ & 161,97 \\
Penerimaan & 114.159 .435 & $14.528 .709,00$ \\
\hline Sumber : Data diolah (2017) & &
\end{tabular}

Padat tebar pada budidaya udang windu relatif sedikit dibandingkan udang vaname yaitu dari 10.000 ekor hingga 75.000 ekor per luasan lahan petambak. Padat tebar udang vaname per usahatani berkisar 50.000 ekor hingga 600.000 ekor.

Pada Tabel 1, produksi serta penerimaan udang vaname dan udang windu memiliki perbedaan yang signifikan. Hal tersebut dikarenakan banyak faktor yang menyebabkan produksi udang vaname lebih tinggi dibanding udang windu. Salah satu faktornya adalah kualitas air tambak, hama penyakit yang menyerang udang, dan lainnya. Beberapa hal tersebut memicu petambak udang windu beralih ke tambak udang vaname.

\section{Analisis Usaha Budidaya Udang}

Nilai penerimaan dapat dihitung dengan melakukan perkalian antara nilai hasil produksi udang dengan harga jual udang baik udang windu maupun udang vaname. Udang windu dan udang vaname memiliki perlakuan budidaya yang hampir sama, namun pada budidaya udang vaname menggunakan lebih banyak input faktor produksi daripada udang windu. Faktor produksi seperti obat-obatan pada budidaya udang vaname, peralatan, serta tenaga kerja yang digunakan juga lebih banyak. Hal tersebut dikarenakan pada budidaya udang vaname memiliki padat tebar benur yang lebih banyak. Padat tebar benur udang mempengaruhi tingkat produksi udang, sehingga mempengaruhi besar kecilnya pendapatan udang.

Padat tebar pada usaha tambak udang windu berkisar 10.000 ekor -70.000 ekor per hektar, sedangkan padat tebar pada udang vaname mulai $60 \mathrm{ekor} / \mathrm{m}^{2}$ hingga $100 \mathrm{ekor} / \mathrm{m}^{2}$. Pada budidaya udang windu memiliki nilai $\mathrm{R} / \mathrm{C}$ sebesar 0,68 , dengan nilai rata-rata penerimaan sebesar Rp14.528.681,00 per hektar. Nilai R/C menunjukkan petambak udang windu mengalami kerugian. Kerugian tersebut dipengaruhi oleh besarnya risiko budidaya yang mempengaruhi petambak beralih usaha budidaya. Petambak yang masih membudidayakan udang windu dikarenakan besarnya biaya yang harus dikeluarkan untuk input budidaya udang vaname. Berikut informasi ratarata penerimaan, biaya dan pendapatan usaha tambak udang vaname disajikan pada Tabel 2 . 
JIIA, VOLUME 8 No. 2, MEI 2020

Tabel 2. Rata-rata penerimaan, biaya, dan pendapatan udang vaname per hektar di Kecamatan Pasir Sakti

\begin{tabular}{|c|c|c|c|c|c|}
\hline No. & Uraian & Satuan & Jumlah $(\mathrm{kg})$ & Harga $(\mathrm{Rp})$ & Nilai (Rp) \\
\hline \multirow[t]{2}{*}{1} & Penerimaan & & & & \\
\hline & Produksi Total & $\mathrm{kg}$ & $1.384,31$ & $82.466,67$ & $114.159 .738,56$ \\
\hline \multirow[t]{30}{*}{2} & Biaya Produksi & & & & \\
\hline & Biaya Tunai & & & & \\
\hline & Benur (Benih Udang) & ekor & $139.869,28$ & 45,33 & $6.340 .740,74$ \\
\hline & Pelet & $\mathrm{kg}$ & $3.119,28$ & $13.427,33$ & $41.883 .626,36$ \\
\hline & Pupuk Urea & $\mathrm{kg}$ & 40,85 & $2.300,00$ & $93.954,25$ \\
\hline & Pupuk Ponska & $\mathrm{kg}$ & 31,05 & $2.600,00$ & $80.718,95$ \\
\hline & Kapur Dolomit & $\mathrm{kg}$ & $1.261,44$ & 684,48 & $863.432,50$ \\
\hline & Kapur $\mathrm{CaCO} 3$ & $\mathrm{~kg}$ & 200,98 & $1.200,00$ & $241.176,47$ \\
\hline & Pest Kupri & $\mathrm{kg}$ & 9,93 & $54.047,62$ & $536.943,67$ \\
\hline & Pest Nofak & $\mathrm{kg}$ & 3,63 & $120.000,00$ & $435.294,12$ \\
\hline & Saponin & $\mathrm{kg}$ & 145,10 & $4.500,00$ & $652.941,18$ \\
\hline & Super NB & 1 & 16,24 & $60.000,00$ & $974.509,80$ \\
\hline & Super PS & 1 & 34,64 & $18.500,00$ & $640.849,67$ \\
\hline & TTCA & 1 & 4,13 & $75.714,29$ & $313.001,87$ \\
\hline & Monodon & $\mathrm{kg}$ & 2,45 & $25.000,00$ & $61.274,51$ \\
\hline & Ariake & $\mathrm{kg}$ & 3,63 & $35.909,09$ & $130.258,47$ \\
\hline & Vitamin B Kompleks & $\mathrm{kg}$ & 0,87 & $105.000,00$ & $90.931,37$ \\
\hline & Vitamin C & $\mathrm{kg}$ & 1,11 & $110.000,00$ & $122.222,22$ \\
\hline & Minyak Cumi & 1 & 10,49 & $34.642,86$ & $363.410,36$ \\
\hline & Pajak & $\mathrm{Rp}$ & & & $28.055,56$ \\
\hline & Biaya Angkut & $\mathrm{Rp}$ & & & $51.633,99$ \\
\hline & Biaya bahan bakar & $\mathrm{Rp}$ & & & $2.637 .254,90$ \\
\hline & TKLK & $\mathrm{Rp}$ & 61,69 & $66.126,60$ & $4.079 .428,05$ \\
\hline & Total Biaya Tunai & $\mathrm{Rp}$ & & & $60.621 .659,01$ \\
\hline & Biaya Diperhitungkan & $\mathrm{Rp}$ & & & \\
\hline & Biaya Penyusutan & $\mathrm{Rp}$ & & & $19.256 .495,30$ \\
\hline & Biaya TKDK & $\mathrm{Rp}$ & 73,47 & $66.126,60$ & $4.858 .468,61$ \\
\hline & Sewa & $\mathrm{Rp}$ & 1,00 & $7.777 .777,78$ & 7.777.777,78 \\
\hline & Total Biaya Diperhitungkan & $\mathrm{Rp}$ & & & $31.892 .741,69$ \\
\hline & Biaya Total & $\mathrm{Rp}$ & & & $92.514 .400,70$ \\
\hline \multirow[t]{5}{*}{3} & Pendapatan Usahatani & & & & \\
\hline & Pendapatan atas Biaya Tunai & $\mathrm{Rp}$ & & & $53.538 .079,55$ \\
\hline & Pendapatan atas Biaya Total & $\mathrm{Rp}$ & & & $21.645 .337,87$ \\
\hline & $\mathrm{R} / \mathrm{C}$ atas Biaya Tunai & $\mathrm{Rp}$ & & & 1,88 \\
\hline & $\mathrm{R} / \mathrm{C}$ atas Biaya Total & $\mathrm{Rp}$ & & & 1,23 \\
\hline
\end{tabular}

Sumber : Data diolah (2017)

Petambak udang windu menentukan padat tebar yang akan ditebar pada kolam tambak sesuai dengan modal yang dimiliki. Luas kolam tambak juga mempengaruhi tingkat pendapatan petambak. Semakin luas kolam yang dimiliki maka semakin tinggi pendapatan udang yang diperoleh petambak. Hasil penelitian ini didukung oleh penelitian Chusnul, Januar, dan Soejono (2010), yang menyatakan nilai $\mathrm{R} / \mathrm{C}$ ratio tinggi disebabkan oleh penerimaan yang tinggi sehingga dapat menutup biaya produksi petambak udang vaname. Hal tersebut diimbangi dengan kualitas udang yang baik, sehingga meningkatkan pendapatan.

Berdasarkan Tabel 2 diperoleh nisbah penerimaan usaha tambak udang vaname ( $\mathrm{R} / \mathrm{C}$ ratio) per hektar sebesar 1,23, sehingga usaha tambak udang vaname menguntungkan bagi petambak. Hal tersebut dapat diartikan bahwa setiap Rp1,00 biaya yang dikeluarkan oleh petambak udang vaname, maka penerimaan yang diperoleh sebesar Rp1,23.

\section{Analisis Risiko Usaha Budidaya Udang}

Risiko yang umum dihadapi petani adalah produksi naik, hama dan penyakit, risiko harga jual (Saputra JE, Prasmatiwi FE, dan Ismono RH 2017). Menurut Saragih, Sukiyono, dan Cahyadinata (2015) cuaca dan iklim seperti curah hujan tinggi saat periode musim tebar mempengaruhi kelancaran proses budidaya udang. Curah hujan tinggi dapat mempengaruhi $\mathrm{pH}$ air kolam, sehingga pertumbuhan udang terganggu. Hama penyakit yang disebarkan oleh virus dan bakteri merupakan kendala utama yang menyebabkan kerugian petambak udang. Tingkat risiko udang windu dan udang vaname dihitung dengan 4 musim tebar (MT) terakhir. Hal tersebut dikarenakan usaha tambak udang vaname belum lama diterapkan di Kecamatan Pasir Sakti. Pada Gambar 1 disajikan grafik rata-rata pendapatan udang windu dan udang vaname pada 4 musim tebar terakhir. 


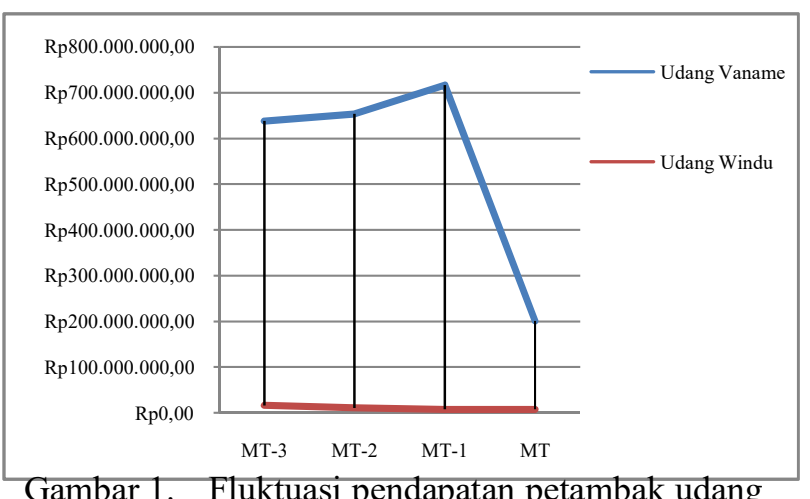

Gambar 1. Fluktuasi pendapatan petambak udang per hektar per musim

Rata-rata produksi udang vaname lebih besar daripada udang windu $(9.026 \mathrm{~kg}>222 \mathrm{~kg})$ per musim. Harga jual rata-rata tertinggi pada udang vaname yaitu Rp84.300,00 pada MT-3, sedangkan rata-rata harga tertinggi udang windu memiliki yaitu Rp89.700,00 pada musim tebar terakhir (MT). Pada Gambar 1 dijelaskan bahwa pendapatan petambak udang vaname tertinggi pada MT-1 yaitu Rp716.866.273,84, sedangkan pada udang windu terletak pada MT-3 yaitu Rp16.882.090,29.

\section{Risiko Usaha Budidaya Udang Windu dan Udang Vaname}

Analisis risiko budidaya udang dilakukan secara statistik dengan menghitung koefisien variasi $(\mathrm{CV})$ dengan mengukur nilai rata-rata $(\mathrm{E})$, standar deviasi (V), dan batas bawah (L). Nilai CV menunjukkan besarnya peluang risiko yang dihadapi petambak udang. Hasil uji hipotesis terhadap risiko disajikan pada Tabel 3.

Berdasarkan Tabel 3 diketahui bahwa usaha budidaya udang vaname memiliki rata-rata produksi sebesar $9.026 \mathrm{~kg}$ dan produksi terendah yang mungkin diterima oleh petambak adalah sebesar $2.384 \mathrm{~kg}$ per 1 hektar. Produksi udang windu rata-rata sebesar $222 \mathrm{~kg}$ dan produksi terendah yang mungkin diterima oleh petambak adalah sebesar $56 \mathrm{~kg}$ per 1 hektar. Harga rata-rata udang vaname pada 4 musim tebar terakhir (E) adalah Rp82.900,00 dan harga terendah yang mungkin diterima oleh petambak adalah Rp69.800,00.

Harga rata-rata udang windu (E) selama 4 musim terakhir adalah $\mathrm{Rp} 87.300,00$ harga terendah yang mungkin diterima petambak udang windu adalah sebesar Rp67.700,00. Pendapatan usaha tambak udang vaname memiliki rata-rata Rp552.434.723,00, sedangkan pendapatan ratarata usaha tambak udang windu (E) selama 4 musim terakhir adalah sebesar Rp10.901.594,00, dan risiko kerugian sebesar Rp5.805.616,00.

$\mathrm{CV}$ risiko produksi, harga, dan pendapatan udang windu lebih tinggi dibandingkan udang vaname, artinya peluang kerugian dengan risiko lebih tinggi terdapat pada usaha tambak udang windu. Hal tersebut dikarenakan serangan hama dan penyakit, dan budidaya udang windu bergantung dengan kondisi air kolam serta cuaca ekstrim (Saragih dkk 2015).

Tabel 3. Hasil uji beda risiko produksi, risiko harga, dan risiko pendapatan udang di Kecamatan Pasir Sakti

\begin{tabular}{|c|c|c|c|c|}
\hline Keterangan & Udang Vaname & Udang Windu & $\mathrm{t}_{\text {hitung }}$ & Sig. \\
\hline \multicolumn{5}{|l|}{ 1. Risiko Produksi } \\
\hline Mean (E) & $9.026,60$ & 222,18 & $6,863 * * *$ & 0,000 \\
\hline Simpangan Baku (V) & $3.320,98$ & 82,93 & $5,700 * * *$ & 0,000 \\
\hline Koefisien Variasi (CV) & 0,28 & 0,35 & $-1,128$ & 0,293 \\
\hline Batas Bawah (L) & $2.384,63$ & 56,31 & $7,976^{* * *}$ & 0,000 \\
\hline \multicolumn{5}{|l|}{ 2. Risiko Harga } \\
\hline Mean (E) & $82.958,33$ & $87.300,00$ & $-1,561$ & 0,141 \\
\hline Simpangan Baku (V) & $6.561,65$ & $9.779,64$ & $-1,744$ & 0,117 \\
\hline Koefisien Variasi (CV) & 0,08 & 0,12 & $-1,582$ & 0,148 \\
\hline Batas Bawah (L) & $69.835,03$ & $67.740,73$ & 0,429 & 0,676 \\
\hline \multicolumn{5}{|l|}{ 3. Risiko Pendapatan } \\
\hline Mean (E) & $552.434 .723,26$ & $10.901 .594,74$ & $5,517 * * *$ & 0,000 \\
\hline Simpangan Baku (V) & $305.656 .128,94$ & $8.353 .605,51$ & $5,529 * * *$ & 0,000 \\
\hline Koefisien Variasi (CV) & 0,58 & 0,95 & $-1,095$ & 0,281 \\
\hline Batas Bawah (L) & $-58.877 .534,61$ & $-5.805 .616,28$ & $-3,896 * * *$ & 0,000 \\
\hline
\end{tabular}


Tabel 4. Hasil analisis faktor yang mempengaruhi petambak mengganti usaha tambak udang windu menjadi udang vaname

\begin{tabular}{lccc}
\hline \multicolumn{1}{c}{ Variabel } & Koefisien & $\begin{array}{c}\text { Odd } \\
\text { Ratio }\end{array}$ & Prob. \\
\hline X1 (Umur) & $-0,0229$ & 0,9774 & 0,8013 \\
X2 (Luas Tambak) & 0,4139 & 1,5132 & 0,6364 \\
X3 (Pengalaman Usahatani) & $-0,0298$ & 0,9706 & 0,8502 \\
X4 (Pendidikan) & $-0,6561^{* *}$ & 0,5187 & 0,0329 \\
X5 (Pendapatan Usahatani) & $0,0000^{* * *}$ & 1,0000 & 0,0084 \\
X6 (Harga Udang Windu & & & \\
dan Vaname) & $-0,0003^{* * *}$ & 0,9997 & 0,0040 \\
\hline LR Statistic & 60,2666 & & \\
Probability (LR Statistic) & $0,0000^{* * *}$ & & \\
McFadden R-Square & 0,7246 & & \\
\hline Sumber : Data diolah (2017) & & & \\
& & & \\
Keterangan : & & & \\
** Berpengaruh nyata dengan kepercayaan 95\% & & \\
***Berpengaruh nyata dengan kepercayaan 99\% & &
\end{tabular}

\section{Analisis Faktor yang Mempengaruhi Petambak Beralih Usaha Tambak Udang}

Peralihan usaha tambak udang windu ke udang vaname dilakukan oleh petambak berdasarkan beberapa faktor eksternal. Sejalan dengan penelitian Sari AM, Ismono $\mathrm{H}$, dan Kasymir E (2015) beberapa faktor yang mempengaruhi alih fungsi lahan usahatani adalah luas lahan, pendapatan, dan harga jual komoditas. Hasil analisis logit disajikan pada Tabel 4.

\section{LR Statistic}

Hasil regresi menunjukkan nilai probability sebesar 0,0000 persen. Nilai tersebut kurang dari 0,01, sehingga variabel bebas umur, luas kolam, pengalaman usahatani, pendidikan, pendapatan usahatani, dan harga udang, secara bersama-sama berpengaruh signifikan terhadap peluang petambak mengganti usaha tambak udang windu ke udang vaname dengan taraf kepercayaan 99 persen.

\section{Mc Fadden R-Square}

Pada Tabel 4 diketahui bahwa nilai Mc Fadden $R$ Square yang dihasilkan adalah sebesar 0,7246. Artinya, sebesar 72,46 persen variasi petambak udang beralih usaha tambak udang windu ke udang vaname dapat dijelaskan oleh variabel umur, luas kolam, pengalaman usahatani, pendidikan, pendapatan usahatani, dan harga udang, sedangkan sisanya sebesar 27,54 persen dapat dijelaskan oleh variabel lain yang tidak dimasukkan ke dalam model.

\section{Parsial Test}

Berdasarkan Tabel 4, umur petambak (X1), luas kolam (X2), dan pengalaman usahatani (X3) tidak berpengaruh nyata terhadap peluang pengambilan keputusan petambak mengganti usaha tambak udang windu ke udang vaname karena nilai probabilitasnya $>0,10$.

Pendidikan (X4) memiliki nilai probabilitas sebesar $0,0329<0,10$, dinyatakan berpengaruh nyata terhadap peluang pengambilan keputusan alih fungsi usaha tambak udang windu menjadi udang vaname dengan taraf kepercayaan 95 persen. Nilai koefisien pendapatan usahatani adalah $-0,6561$ dengan peluang petambak beralih usaha tambak udang sebesar 0,5 kali. Semakin tinggi tingkat pendidikan maka inovasi baru dapat dengan cepat dipahami oleh petambak.

Pendapatan usahatani (X5) berpengaruh nyata terhadap peluang pengambilan keputusan alih fungsi usaha tambak udang dengan taraf kepercayaan sebesar 99 persen. Nilai koefisien pendapatan usahatani adalah 0,000000271 dengan peluang petambak beralih usaha tambak udang sebesar 1 kali. Pendapatan usaha tambak udang vaname lebih tinggi dibandingkan udang windu, sehingga tidak sedikit petambak beralih usaha tambak udang.

Harga udang windu dan udang vaname (X6) berpengaruh nyata terhadap peluang pengambilan keputusan alih fungsi usaha tambak udang windu ke udang vaname dengan taraf kepercayaan sebesar 99 persen. Semakin tinggi harga jual udang vaname, maka akan semakin besar keinginan petambak beralih dari usaha tambak udang windu ke udang vaname. Nilai koefisien harga udang windu dan udang vaname adalah 0,000287 dengan peluang petambak beralih usaha tambak udang windu menjadi udang vaname adalah sebesar 1 kali.

\section{KESIMPULAN}

Pendapatan usaha tambak udang vaname lebih tinggi dibandingkan udang windu. Tingkat produksi dan pendapatan udang vaname lebih tinggi dibandingkan dengan udang windu, namun udang windu memiliki harga jual yang lebih tinggi daripada udang vaname. Risiko usaha budidaya udang windu lebih besar dibandingkan dengan udang vaname. Pendidikan serta harga udang windu dan udang vaname berpengaruh negatif, sedangkan pendapatan usahatani berpengaruh positif terhadap peluang pengambilan keputusan alih fungsi usaha tambak udang windu ke udang vaname. 


\section{DAFTAR PUSTAKA}

BPS [Badan Pusat Statistik Provinsi Lampung]. 2014. Produk Domestik Regional Bruto Provinsi Lampung Menurut Lapangan Usaha. BPS Provinsi Lampung. Bandar Lampung.

Chusnul DZ, Januar J, dan Soejono D. 2010. Kajian sosial ekonomi usaha budidaya udang vaname (Litopenaeus vaname) di Desa Dinoyo Kecamatan Deket Kabupaten Lamongan. Jurnal Sosial Ekonomi Pertanian, 4 (1) : Hal 15-23. Universitas Jember. https://jurnal.unej.ac.id /index.php /JSEP/article/view/366/224. [20 September 2018].

Ibrahim A. 2012. Tataniaga Pertanian. Universitas Lampung. Bandar Lampung.

Frankel J dan Wallen N. (1993). How to Design and evaluate research in education. (2nd ed). McGraw-Hill Inc. New York.

Gay LR dan Diehl PL. 1992. Research method for bissines and management. MacMillan Publishing Company. New York.

Kadarsan HW. 1992. Keuangan Pertanian dan Pembiayaan Agribisnis. Gramedia Pustaka Utama. Jakarta.

Kementerian Kelautan dan Perikanan RI. 2016. Info Harga Ikan Republik Indonesia. Dirjen Penguatan Daya Saing Produk Kelautan. Jakarta.

Kordi K. 2011. Budidaya 22 Komoditas Laut untuk Konsumsi Lokal dan Ekspor. Andi Publisher. Yogyakarta.

Kristina Y. 2014. Analisis faktor faktor yang mempengaruhi produksi dan pendapatan budidaya tambak udang vaname di Kecamatan Pasekan Kabupaten Indramayu. Skripsi. Fakultas Ekonomi dan Manajemen Institut Pertanian Bogor. Bogor. https:// repository.ipb.ac.id/jspui/bitstream/1234567 89 /69676/1/H14ykr.pdf. [10 September 2018].
Kuncoro M. 2004. Metode Riset untuk Bisnis dan Ekonomi. Penerbit Erlangga. Jakarta.

Pasaribu MC. 2016. Nilai ekonomi perubahan penggunaan lahan usahatani kopi menjadi kakao di Kecamatan Bulok Kabupaten Tanggamus. Skripsi. Fakultas Pertanian Universitas Lampung. Bandar Lampung.

Putri A, Widjaya S, dan Kasymir E. 2018. Pendapatan usahatani polikultur udang windu-ikan bandeng dan efisiensi pemasaran ikan bandeng di Kecamatan Pasir Sakti Kabupaten Lampung Timur. JIIA, 6 (3) : 242-248. Universitas Lampung. Bandar Lampung. http://jurnal.fp.unila.ac.id/index .php/JIA/article/view/3020/2409. [24 Agustus 2019].

Saputra JE, Prasmatiwi FE, dan Ismono RH. 2017. Pendapatan dan risiko usahatani jahe di Kecamatan Penengahan Kabupaten Lampung Selatan. JIIA, 5 (4) : 392-398. Universitas Lampung. Bandar Lampung. http://jurnal.fp.unila.ac.id/index .php/JIA /article/view/1748/1551. [24 Agustus 2019].

Saragih NS, Sukiyono K, dan Cahyadinata I. 2015. Analisis risiko produksi dan pendapatan budidaya tambak udang rakyat di Kelurahan Labuhan Deli, Kecamatan Medan Marelan, Kota Medan. Jurnal Agrisep, 14 (1) : 39-52 . Universitas Bengkulu. Bengkulu. https://ejournal.unib.ac.id/index.php/agrisep/ article/view/593/534. [26 Desember 2016].

Sari AM, Ismono H, dan Kasymir E. 2015. Alih fungsi lahan padi menjadi karet di daerah Irigasi Way Rarem Pulung Kencana Kabupaten Tulang Bawang Barat. JIIA, 3 (4) : 336-344. Universitas Lampung. Bandar Lampung. http://jurnal.fp.unila.ac.id/index .php/JIA/article/view/1082/987. [24 Agustus 2019].

Soekartawi. 2006. Analisis Usahatani. UI Press. Jakarta.

Sugiyono. 2003. Metode Penelitian Bisnis Edisi 1. Alfabeta. Bandung. 